\title{
KEY ASPECTS OF ORGANIZATION OF THE PROCESS AND INDIVIDUAL CHARACTERISTICS OF NUTRITION OF PUPILS AND STUDENTS OF DIFFERENT TYPES OF MODERN EDUCATIONAL INSTITUTIONS
}

DOI: 10.36740/WLek202109124

\author{
Oksana V. Tymoshchuk ${ }^{1}$, Zhanna V. Sotnikova-Meleshkina ${ }^{2}$, Olha P. Melnyk-Sheremeta', Oksana V. Zahorodnieva², \\ Krystyna A. Kryvonos ${ }^{2}$, Kseniia M. Ostrovska' \\ 'IVANO-FRANKIVSK NATIONAL MEDICAL UNIVERSITY, IVANO-FRANKIVSK, UKRAINE \\ ${ }^{2}$ V. N. KARAZIN KHARKIV NATIONAL UNIVERSITY, KHARKIV, UKRAINE
}

\begin{abstract}
The aim: Study the key aspects of organization of the process and individual characteristics of nutrition of pupils and students of different types of modern educational institutions. Materials and methods: To adequately assess the process of organization of the regime and individual characteristics of nutrition of pupils and students of different types of modern educational institutions, we have evaluated the key characteristic features of a rational diet: number of daily meals and their duration, food consumption rate, conditions and priorities as well as distribution of dish volume and caloric content in accordance with food intake frequency.

Results: The results of the study have shown a significantly high rate of abuses in individual diet key components. Thus, majority of pupils and students do not observe proper food intake frequency, often skip their main meals, fail to maintain proper time intervals between meals, spent insufficient time for their main meals, incorrectly distribute food volume and caloric content according to the number of meals, do not have breakfast, consume the largest volume of food for their supper, eat their meals at a quick rate, and, certainly, abuse street and fast food.

Conclusions: The revealed violations of the basic nutrition principles and patterns may be the cause of functional disorders and adaptive incapabilities of the body, as well as the development of various polynutrient deficiencies and food-related diseases, therefore requiring justification and implementation of the possible ways of their correction.
\end{abstract}

KEY WORDS: nutrition, rational regime, pupils, students, educational institutions

Wiad Lek. 2021;74(9 p.l):2163-2168

\section{INTRODUCTION}

Nowadays, health condition of the young generation of our state can be characterized as unsatisfactory. Crucial criteria determining health status include high morbidity and mortality, hence low life expectancy [1]. Undoubtedly, nutrition is one of the major factors influencing the level of maintaining and strengthening the health of the population. Recent medical trials and epidemiological studies have proved the presence of direct influence of nutrition patterns on the development of diseases of the gastrointestinal tract, genitourinary, endocrine, and cardiovascular systems, as well as certain types of malignancies. Excessive consumption of high-calorie foods, including fats, simple carbohydrates, and table salt, as well as daily diet deficiencies of vitamins and dietary fibers can be the cause of some degenerative disorders, namely cardiovascular diseases, some types of cancer, diabetes, gallstones disease, obesity, gout, etc. $[2,3]$. As a matter of fact, people living in the Mediterranean region, who traditionally consume much olive oil, variety of fruits and vegetables, but small amount of meat products, as well as those living in Southeast Asia, China, Japan and Africa, who mainly follow plant and vegetarian diet, have 2-3 times lower detection rate of cardiovascular diseases and various malignancies as compared to the rate among people, who are in favour of the traditional Western European cuisine, which is based on excessive consumption of meat and dairy products, fats, simple carbohydrates, and table salt but insufficient consumption of vegetables and fruits [4].

In recent decades, both in Ukraine and abroad, the development of nutritional sciences is inseparably associated with the theory of balanced nutrition, in accordance with the laws of which there have been developed nutritional standards and diets for various age groups and occupational categories in the light of existent climate conditions, physical and mental workload, and recommended daily allowance.

According to the WHO, the health of the population is $70 \%$ dependent on lifestyle, the main component of it being nutrition. Rational nutrition creates proper conditions for optimal growth and development of children and youth, prevents rise in disease incidence rate, provides increase in life expectancy and is an integral part of creating conditions that ensure adequate adaptation to the environment [5]. 


\section{THE AIM}

The purpose of the research is to study the key aspects of the organization of the process and individual characteristics of nutrition of pupils and students of modern educational institutions of different types.

\section{MATERIALS AND METHODS}

For optimal growth and development as well as proper body functioning of adolescents, foodstuff provision is a mandatory requirement. But one must bear in mind, that the foodstuff mustn't be chosen at random. Not only the caloric or energy value the body receives is important, the vitamins, trace elements and minerals a young person ingests also play a great role. Food is a source of energy and a building material, in the absence of which various disorders as well as acute and chronic illnesses may develop.

Observance of nutrition principles by the youth is equally important, thus, the research program included a detailed analysis of all the components of organization of rational dietary regime, as well as the study of quantitative and qualitative nutritional facts of students' habitual foodstuff. The research has revealed that the pupils and students being subject to our study exhibited mainly two types of eating habits. Three meals a day pattern was typical for establishments without catering on a regular basis, four meals a day pattern was observed in institutions, in which four meals a day were provided at the expense of the state budget. Rational nutrition of pupils and students helps them maintain and strengthen their health, increases the body's resistance to negative environmental impact, provides opportunities for high physical activity and mental performance, as well as prolongs active way of life.

Our investigation has been conducted in the light of the diversity of scope of modern educational institutions, thus including Vasyl Stefanyk Precarpathian National University, S. Hranat IFFC College, Ivano-Frankivsk State Music Vocational School named after Denys Sichynskyi, Ivano-Frankivsk Lyceum No. 15 and Ivano-Frankivsk boarding school for gifted young people from rural areas. A total of 420 respondents took part in the survey. Pupils and students of modern educational institutions, including 210 girls and 210 boys, who were in both natural and preformed conditions, were subject to observation for indepth study of the condition and characteristic features of their individual nutrition.

To warrant quantitative representativeness and validity, the composition of individual groups of respondents was formed by means of special mathematical formulas that determine the scope of statistical sampling, thus ensuring the reliability of the results. The minimum number of respondents in each of the groups that had to be included in the research both in natural conditions (comparison groups, which included young people from educational institutions of different types and, therefore, with different modern approaches to organizing educational activities of pupils and students), and in preformed conditions (comparison groups having been formed for conducting the hygienic experiment, which involved application of the program of psychophysiological effects on the body, psychohygienic correction of the processes of personality formation and improvement of the quality of life of pupils and students) was chosen taking into account the value of maximum error $(\varepsilon)$ as well as the value set up according to the tables in conformity with the confidence probabilities $(\alpha=\Phi(\mathrm{z}))$, under conditions when the approximate value of the standard deviation $(\sigma \mathrm{x})$ is known by calculating the distribution of these indicators and the probability integral of the Laplace function by means of the following formula (1):

$$
\mathrm{n}=\frac{\mathrm{Z}^{2} \sigma_{\mathrm{x}}{ }^{2}}{\varepsilon^{2}} ;
$$

To ensure a high degree of homogeneity of the research groups in order to adequately compare the results, we have always given consideration to such characteristics as age and gender, relative unity and absolute comparability of the main characteristics of the conditions of educational and extracurricular activities, eating habits and adherence to the principles of rational nutrition. In our research, we applied the sanitary-hygienic and medical-sociological methods of investigation.

To adequately assess the process of organization of the regime and individual characteristics of nutrition of pupils and students of different types of modern educational institutions, we have evaluated the key characteristic features of a rational diet: number of daily meals and their duration, food consumption rate, conditions and priorities as well as distribution of dish volume and caloric content in accordance with food intake frequency.

While examining food intake frequency, it was found out that the majority of respondents have their meals only twice a day $-44.5 \%$ of boys and $49.5 \%$ girls studying at university, $46.6 \%$ of boys and $48.1 \%$ of girls studying at college, $43.8 \%$ of boys and $47.9 \%$ of girls studying at vocational school, $41.4 \%$ of boys and $38.6 \%$ of girls studying at lyceum, as well as $28.7 \%$ of boys and $52.3 \%$ of girls studying at school; three times a day $-35.7 \%$ of university boys and $30.6 \%$ of university girls, $40.6 \%$ of college boys and $32.6 \%$ of college girls, $36.4 \%$ of boys and $33.9 \%$ of girls studying at vocational school, $32.7 \%$ of lyceum boys and $29.5 \%$ of lyceum girls, as well as $61.2 \%$ of school boys and $41.4 \%$ of school girls; four times a day $-18.4 \%$ of boys and $8.2 \%$ of girls studying at university, 9.5\% of college boys and $7.3 \%$ of college girls, $14.7 \%$ of boys and $7.1 \%$ of girls studying at vocational school, $18.8 \%$ of lyceum boys and $18.1 \%$ of lyceum girls, as well as $7.3 \%$ of boys and $4.1 \%$ of girls studying at school; more than four times a day $-1.4 \%$ of university boys and $2.6 \%$ of university girls, $3.3 \%$ of boys and $3.6 \%$ of girls studying at college, $5.1 \%$ of boys and $3.0 \%$ of girls studying at vocational school, $7.1 \%$ of lyceum boys and $3.6 \%$ of lyceum girls, as well as $2.8 \%$ of boys and $2.2 \%$ of girls studying at school (See Figs. 1,2). In addition, the fact that with the aim of losing weight a substantial proportion of girls (from $8.1 \%$ studying at vocational school 

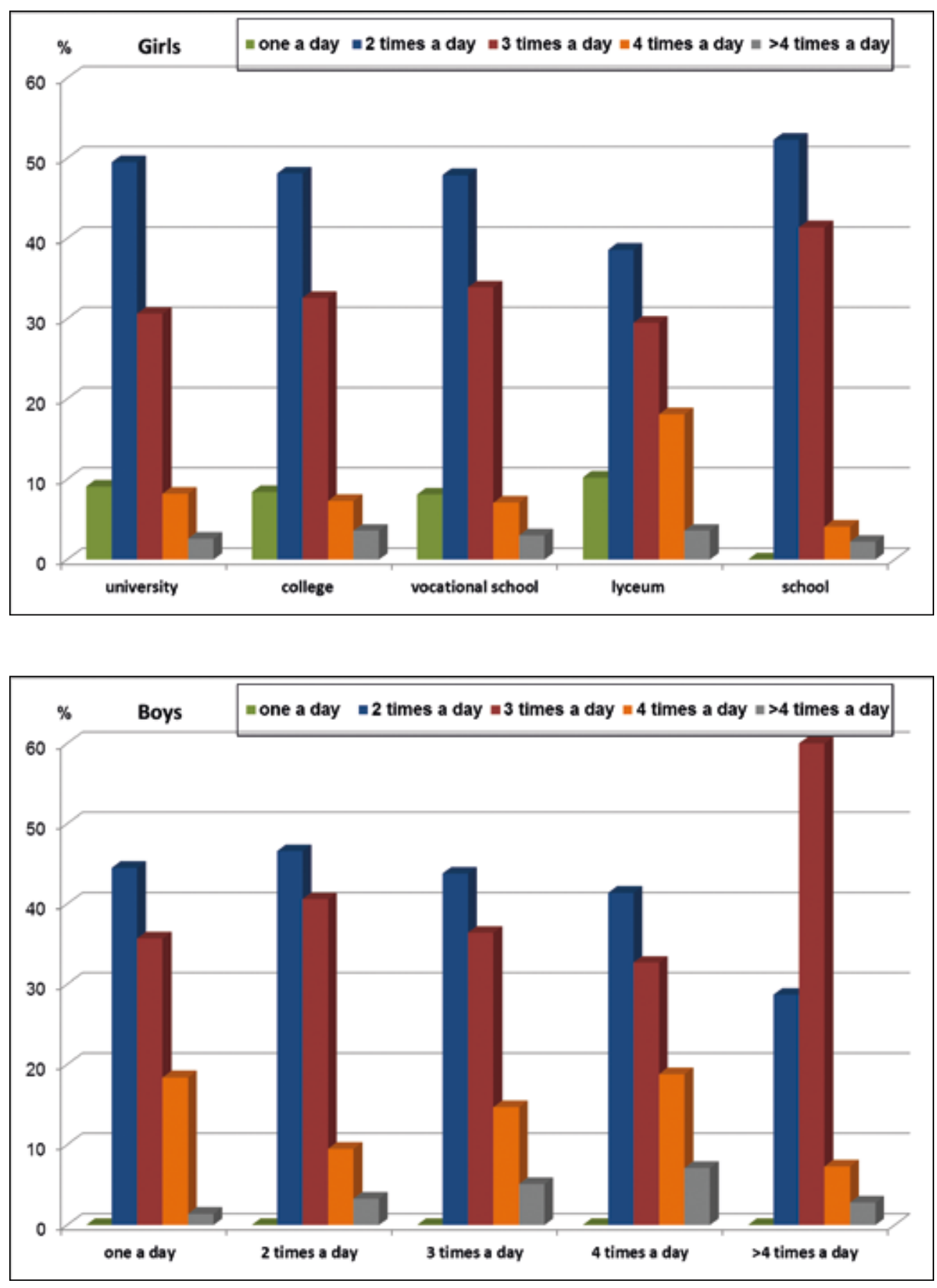

Fig. 1. Food intake frequency, girls

Fig. 2. Food intake frequency, boys

to $10.2 \%$ studying at lyceum) eat a wholefood meal only once a day is of significant concern. Such a tendency has been observed among girls of all educational institutions of different types, except for the school, in which three meals a day were provided at the expense of the state budget. It should also be noted that among a significant proportion of respondents $(36.1 \%-44.9 \%)$ including both boys and girls it is a custom to skip morning meals, the reason for which the young people explain in different ways: lack of time, no appetite, malaise, etc.

While analysing the distribution of food volume consumed in accordance with food intake frequency, we have paid attention to the fact that only a small proportion of pupils and students distribute it consistently. The largest amount of food consumed for breakfast $-10.8 \%$ of boys and $4.4 \%$ of girls studding at university, $10.2 \%$ of college boys and $5.8 \%$ of college girls, $11.3 \%$ of boys and $5.8 \%$ of girls studying at vocational school, $11.1 \%$ of lyceum boys and $4.3 \%$ of lyceum girls, as well as $12.3 \%$ of school boys and $6.4 \%$ of school girls; for lunch $-42.8 \%$ of university boys and $77.3 \%$ of university girls, $47.5 \%$ of college boys and $76.8 \%$ of college girls, $44.2 \%$ of boys and $76.7 \%$ of girls studying at vocational school, $45.8 \%$ of lyceum boys and $77.5 \%$ of lyceum girls, as well as $41.1 \%$ of school boys and $73.7 \%$ of school girls; for dinner $-46.4 \%$ of university boys and $18.3 \%$ of university girls, $42.3 \%$ of college boys and $17.4 \%$ of college girls, $44.5 \%$ of boys and $17.5 \%$ of girls studying at vocational school, $43.1 \%$ of lyceum boys and 

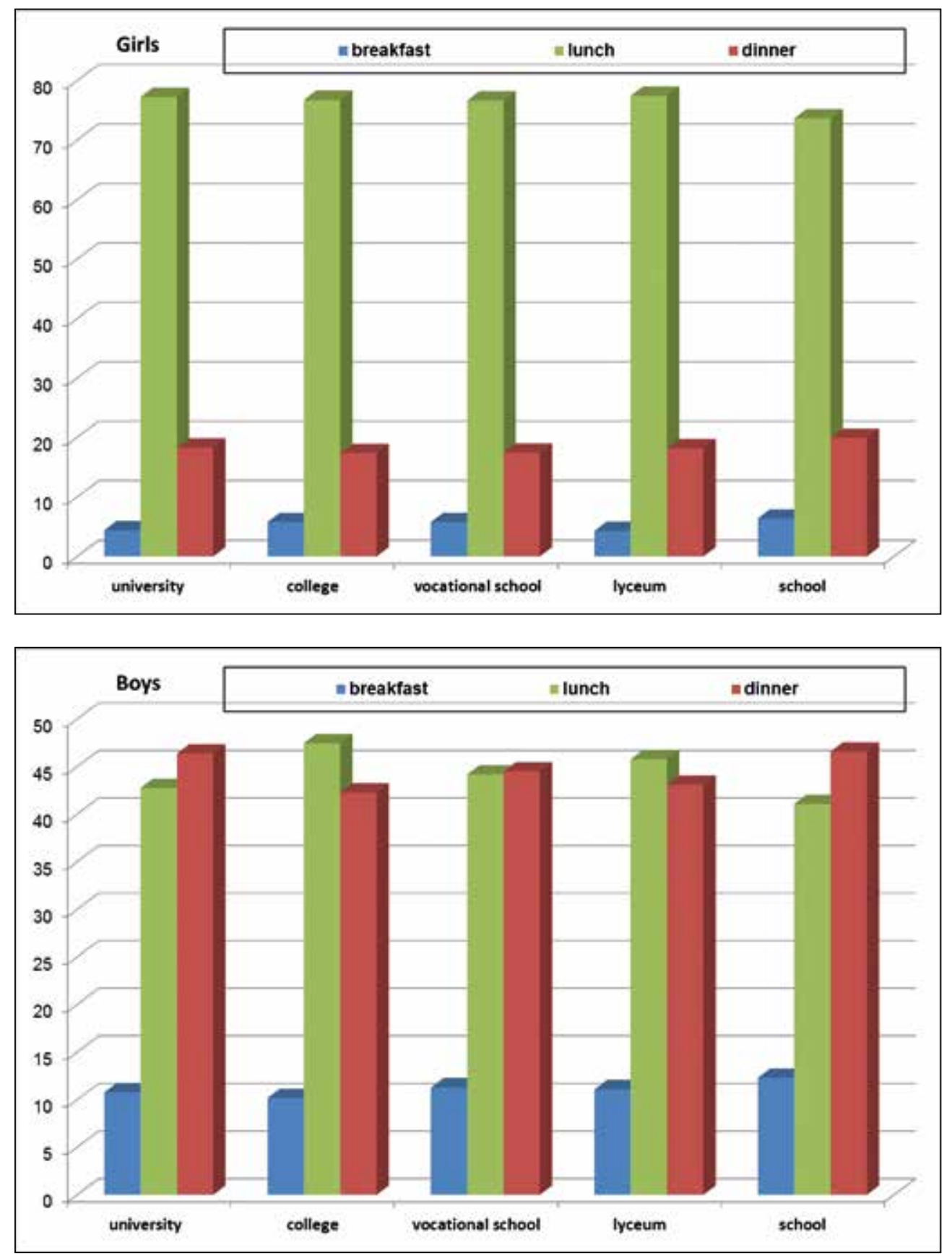

Fig. 3. The distribution of food volume consumed in accordance with food intake frequency, girls

Fig. 4. The distribution of food volume consumed in accordance with food intake frequency, boys
$18,2 \%$ of lyceum girls, as well as $46.6 \%$ of boys and $19.9 \%$ of girls studying at school (See Figs. 3, 4).

While assessing the rate of food consumption among the respondents, we have noted that the majority of both boys and girls consume their meals hasty and very hasty, and only a small number of the young people eat at a moderate and slow pace. It should be noted that more than $30 \%$ of the respondents do not consume their food at table, but rather in some other locations (in front of a computer screen, in bed, in a car, etc.). It is interesting that more young men than girls employ catering establishments: cafeterias, canteens, cafes, restaurants, as well as fast food and street food outlets. It has been found out that about $40 \%$ of boys and about $45 \%$ of girls prefer junk food, whereas about $62 \%$ of males and $51 \%$ of females have hot and first meals in their diet on a daily basis. It has been noted that from $78.4 \%$ to $82.5 \%$ of boys and from $73.7 \%$ to $80.1 \%$ of girls do not consume their meals at the same time of day.

\section{RESULTS}

In today's society, young people do not fully appreciate the role of a balanced diet and the presence of quality and healthy foods in their daily ration as well as its impact on individual health and increase of duration and quality of life. There is a significant proportion of young people who are unaware of the principles of healthy diet and are careless about their nutrition.

The period of study at different types of educational institutions coincides with the period of intensive growth 
and development of boys and girls: increase in body weight, active skeleton development and muscle mass growth, significant neurohormonal alteration of important body processes and functions, sexual maturation, change in neuro-psychological sphere, when there is a significant tension of adaptation processes, increase of mental and information load, and energy expenditure. Therefore, during this period, it is extremely important to follow principles of rational nutrition and to create conditions for ensuring 4-5-time daily intake of quality safe food for all the categories of pupils and students being it in educational institutions or at home $[6,7]$.

Assessment of the general health, psychophysiological functions, adaptive capacities and functional indicators of pupils and students are important factors that might influence the need for immediate review of the structure and organization of modern educational institutions, introduction of innovative technologies at each stage of educational process and improvement of the existing ones, as well as development of various types of novel preventive and health measures, thus ensuring organization of nutrition in various types of modern educational institutions.

\section{DISCUSSION}

High rates of physical and mental growth and development, and extremely intense psychophysiological, mental, social, communicative, adaptive tension cannot be overcome without regular provision of the body with a full range of balanced foods and compliance with the appropriate regime and principles of nutrition. This concept must be adhered both at home and in different types of educational institutions, where boys and girls spend much of their time $[8,9]$. This requirement can be provided and implemented only in the light of all the innovative areas of development of modern nutrition science and putting into practice students' balanced diet at educational institutions.

Having analysed the results of the survey of individual nutrition patterns of pupils and students of different types of modern educational institutions, it is safe to say that the key factors causing abuses in the regime of nutrition and balanced diet are economic and financial capabilities of the family, customs and traditions in consuming of certain foods and dishes, eating habits and relatively low level of knowledge about the principles of rational nutrition.

The way to solve the problem of optimization of the process of nutrition of pupils and students consists in the introduction of a modern industrial platform for nutrition, as well as dynamic educational work on the importance of adherence to the principles of rational nutrition among pupils and students, their parents and teachers. In order to ensure the achievement of this goal, it is necessary to organize foundation for economic, legal, social as well as material and technical resources for implementation of rational nutrition of pupils and students in educational institutions of our state. Taking into account the current state and quality of nutrition in educational institutions and the achievements of a number of neighbouring countries in this issue, the concept of nutrition in different types of modern educational institutions has been developed. The concept takes into account individual characteristics of boys and girls and is aimed at provision of rational nutrition, thus at maintaining general well-being and prevention of growth of acute and chronic disorders and diseases, which can be caused by nutritional status disturbances.

The results of the study have shown significantly high values of violation of the main components of individual nutrition regime. Thus, majority of pupils and students do not observe proper food intake frequency, often skip their main meals, fail to maintain proper time intervals between meals, spent insufficient time for their main meals, incorrectly distribute food volume and caloric content according to the number of meals, do not have breakfast, consume the largest volume of food for their supper, eat their meals at a quick rate, and, certainly, abuse street and fast food.

It should be noted that the state of health of pupils and students directly depends on the individual characteristics of nutrition and directly affects the quality of training of young professionals of various spheres, as learning process at different types of modern educational institutions requires significant mental, emotional and physical load, and to a large extent causes tension of adaptation processes $[10,11]$.

\section{CONCLUSIONS}

The revealed violations of the basic nutrition principles and patterns may be the cause of functional disorders and adaptive incapabilities of the body, as well as the development of various polynutrient deficiencies and food-related diseases, therefore requiring justification and implementation of the possible ways of their correction.

Normal body functioning is accomplishable by following the principles of rational nutrition, thus providing quality and quantity adequacy, covering all energy consumption, promoting normal growth and development, helping to overcome the negative impact of the environment, improving physical and mental performance and therefore providing conditions for adequate growth and development.

\section{REFERENCES}

1. Dogareva N.G., Stadnikova S.V., Rebezov M.B. Creation of new types of products from raw materials of animal origin and non-waste technologies for their production. University procedia as a regional center of education, science and culture. Orenburg, 2012; 945-953 p.

2. Tymoshchuk O.V., Zhurakivska O.Y., Derpak V.V. et al. Special aspects of the efficient daily routine of students at modern educational establishments of different types. Wiad Lek., 2020;7:1516-1521.

3. Marushko Yu.V., Taryns'ka 0.L. Kharchuvannya students'koi molodi yak chynnyk zdorovoho sposobu zhyttya. Skhidnoyevropejs'kyj zhurnal hromads'koho zdorov'ya, 2013; 189-190.

4. Serdyuk A.M., Hulich M.P. Polityka v haluzi kharchuvannya naselennya holovnyj priorytet derzhavy. Dovkillya ta zdorov'ya, 2002;3: 38-43.

5. Gayazova A.O., Rebezov M.B., Pauls E.A. et al. Perspective directions of development of production of meat semi-finished products. The Young Scientist 2014; 9(68): 127-129. 
6. Mel'nyk V.I. Hihiyenichna ocinka umov navchannya ta osoblyvosti psykhofiziolohichnoho stanu studentiv u period zaprovadzhennya innovacijnykh metodiv u navchal'nyj proces vyschykh navchal'nykh medychnykh zakladiv: avtoref. dys. na zdobuttya nauk. stupenya kand. med. nauk: spec. 14.02.01 "Hihiyena ta profesijna patolohiya". Kyiv, 2016, 20 p.

7. Zinina 0.V., Rebezov M.B., Solovyova A.A. Biotechnological processing of meat raw materials. V. Novgorod: Novgorod Technopark, 2013, 272 p.

8. "Zdorov'ya-2020": Osnovy Yevropejs'koi stratehii u pidtrymku dij vsiyei derzhavy i suspil'stva v interesakh zdorov'ya i blahopoluchchya. Kopenhahen: YeRB V00Z, 2012; 127 p.

9. James W.P. Healthy nutrition. WHO Regional Publications, Europian Series. 1988;24: 150.

10. Smolyar V.I. Stan faktychnoho kharchuvannya naselennya nezalezhnoi Ukrainy. Problemy kharchuvannya, 2012;34-35: 5-9.

11. Odegaard A.O., Jacobs Jr.D.R., Steffen L.M. Breakfast frequency and development of metabolic risk. Diabetes Care. 2013;36: 3100-3106.

\section{ORCID and contributionship:}

Oksana V. Tymoshchuk: 0000-0001-9179-9951 A, B,D,F

Zhanna V. Sotnikova-Meleshkina: 0000-0001-5534-8264 ${ }^{B, E, F}$

Olha P. Melnyk-Sheremeta: 0000-0001-6775-7815 A,B,D, F

Oksana V. Zahorodnieva: 0000-0002-3403-4984 D, E, F

Krystyna A. Kryvonos: 0000-0003-0302-0835 D, E, F

Kseniia M. Ostrovska: 0000-0002-2402-4539 ${ }^{\text {B, }}$

\section{Conflict of interest:}

The Authors declare no conflict of interest.

\section{CORRESPONDING AUTHOR}

\section{Oksana V. Tymoshchuk}

Ivano-Frankivsk National Medical University

2 Halytska st., 76493 Ivano-Frankivsk, Ukraine

tel: +380991633529

e-mail: oksanavorob4ak@gmail.com

Received: 17.05 .2021

Accepted: 19.08 .2021

A - Work concept and design, B - Data collection and analysis, C - Responsibility for statistical analysis,

D-Writing the article, $\mathbf{E}$-Critical review, $\mathbf{F}$ - Final approval of the article 